\title{
Karakteristik Personal dalam Memoderasi Pengaruh Penganggaran Partisipatif dan Ambiguitas Peran pada Senjangan Anggaran
}

\author{
Yoana Dharmawan ${ }^{1}$ \\ Fakultas Ekonomi dan Bisnis \\ Universitas Udayana, Indonesia
}

\author{
Made Gede Wirakusuma² \\ Fakultas Ekonomi dan Bisnis \\ Universitas Udayana, Indonesia
}

Surel : yoanadharmawan@gmail.com

\section{ABSTRAK}

Penelitian ini bertujuan untuk mengetahui peran karakteristik personal dalam memoderasi pengaruh penganggaran partisipatif terhadap senjangan anggaran dan untuk mengetahui peran karakteristik personal dalam memoderasi pengaruh ambiguitas peran terhadap senjangan anggaran. Data yang dipergunakan dalam penelitian ini adalah data primer, teknik analisis yang digunakan adalah Moderated Regression Analysis (MRA). Hasil analisis menunjukkan karakteristik personal memperlemah pengaruh penganggaran partisipatif pada senjangan anggaran. Hal ini menunjukkan dengan adanya karakteristik personal yang baik maka partisipatif anggaran akan mampu mengurangi terjadinya senjangan anggaran. Karakteristik personal memperlemah pengaruh ambiguitas peran senjangan anggaran. Hal ini menunjukkan bahwa adanya karakteristik personal yang baik maka ambiguitas peran akan berkurang dan mampu mengurangi terjadinya senjangan anggaran.

Kata Kunci: $\quad$ Karakteristik Personal; Penganggaran Partisipatif; Ambiguitas Peran; Senjangan Anggaran.

\section{The Role Personal Characteristics Moderating Effects Participatory Budgeting and Role Ambiguity on Budgetary Slack}

\begin{abstract}
This study aims to determine the role of personal characteristics in moderating the effect of participatory budgeting on budgetary slack and to determine the role of personal characteristics in moderating the influence of role ambiguity on budgetary slack. Data used is primer data, the analysis technique used in this study is Moderated Regression Analysis. The results of the analysis address personal characteristics which weaken the effect of participatory budgeting on budgetary slack. This shows that with good personal characteristics, participatory budgets will be able to reduce budgetary slack events. Personal characteristics weaken the influence of role ambiguity on budgetary slack. This shows that good personal characteristics, the role ambiguity will be reduced and will able to reduce the budgetary slack.
\end{abstract}

Keywords: Personal Characteristics; Participatory Budgeting; Role Ambiguity; Budgetary Slack.

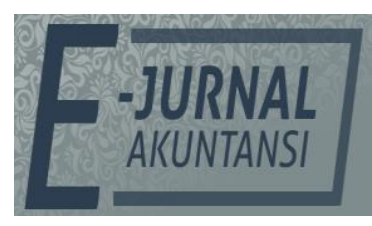

e-ISSN 2302-8556

Vol. 31 No. 2

Denpasar, Februari 2021

Hal. 360-373

DOI:

10.24843/EJA.2021.v31.i02.p08

PENGUTIPAN:

Dharmawan, Y., \&

Wirakusuma, M.G. (2021).

Karakteristik Personal dalam

Memoderasi Pengaruh

Penganggaran Partisipatif dan Ambiguitas Peran pada

Senjangan Anggaran. EJurnal Akuntansi, 31(2), 360

373

RIWAYAT ARTIKEL: Artikel Masuk: 9 Maret 2020 Artikel Diterima: 7 Februari 2021

Artikel dapat diakses : https://ojs.unud.ac.id/index.php/Akuntansi/index 


\section{PENDAHULUAN}

Perkembangan bisnis dan persaingan antar perusahaan semakin ketat. Persaingan global akan menyebabkan suatu ketidakpastian dalam lingkungan bisnis sehingga menimbulkan kesulitan dalam proses perencanaan dan pengendalian manajemen. Manajemen dituntut untuk merencanakan masa depan perusahaan dengan sungguh-sungguh, sehingga perusahaan dapat bertahan dan bersaing dalam kompetisi yang ketat. Kemajuan perusahaan sangat bergantung pada pengelolaandan kegiatan manajemen yang terkait dengan proses perencanaan dan pengendalian. Perencanaan menentukan tindakantindakan apa yang dilakukan untuk merealisasikan tujuan tertentu, sedangkan pengendalian menilai apa yang telah dihasilkan dan membandingkannya dengan rencana yang telah disusun.

Pesatnya perkembangan persaingan bisnis yang ada saat ini memberikan risiko yang tinggi terhadap bagian keuangan perusahaan tersebut, dimana keuangan merupakan alat pengukur sehat atau tidak sehatnya sebuah perusahaan. Fenomena yang terjadi ini juga tidak luput dialami oleh perusahaan perhotelan. Perusahaan perhotelan yang saat ini menjadi sorotan adalah hotelhotel yang ada di Kota Denpasar. Hal ini mengingat Kota Denpasar merupakan pusat pemerintahan dan ibu Kota dari Provinsi Bali. Selain itu, Kota Denpasar juga menjadi salah satu agenda destinasi pariwisata bagi wisatawan yang berkunjung ke Bali, baik itu wisatawan lokal, domestik ataupun mancanegara.

Anggaran merupakan salah satu alat manajemen yang berfungsi sebagai alat perencanaan dan pengendalian serta dapat meningkatkan kinerja organisasi dalam mencapai tujuan jangka pendek maupun jangka panjang. Manajemen dalam hal ini dituntut untuk merencanakan masa depan keuangan dengan sungguh-sungguh sehingga perusahan perhotelan dapat bertahan dan bersaing dalam kondisi yang tepat. Anggaran merupakan pernyataan mengenai estimasi kinerja yang hendak dicapai selama periode waktu tertentu yang dinyatakan dalam ukuran finansial. Anggaran memiliki dampak langsung terhadap perilaku manusia. Orang-orang merasakan tekanan dari anggaran yang ketat dan kegelisahan atas laporan kinerja yang buruk sehingga anggaran seringkali dipandang sebagai penghalang kemajuan karier mereka. Oleh karena itu, keikutsertaan manajer dalam penyusunan anggaran atau anggaran partisipatif dapat mendorong penetapan anggaran yang tepat.

Keikuttsertaan manajer di dasarkan pada Agency Theory yang menyatakan bahwa pemilik (principal) mendelegasikan kepada bawahan (agent) untuk bertanggungjawab melakukan suatu tugas dan membuat keputusan. Prinsipal adalah pemilik atau pemegang saham perusahaan sedangkan agent adalah pengelola atau manajer perusahaan sehingga pada perusahaan perhotelan, manajer hotel diberikan wewenang dalam melakukan penyusunan anggaran oleh direktur hotel. Selanjutnya, hasil studi empiris Irfan et al., (2016), menyatakan adanya keterlibatan manajer tingkat bawah/menengah dalam penyusunan anggaran justru dapat menimbulkan terjadinya senjangan anggaran.

Senjangan anggaran biasanya dilakukan dengan meninggikan biaya atau menurunkan pendapatan dari yang seharusnya, supaya anggaran mudah dicapai. Senjangan anggaran dapat terjadi karena manajer berusaha untuk 
mencari cara melindungi dirinya sendiri dari risiko tidak tercapainya target anggaran (Ajibolade \& Opeyemi, 2014). Banyak penelitian yang dilakukan untuk menganalisa faktor- faktor yang dapat menimbulkan senjangan anggaran. Salah satu faktor yang banyak diteliti dan dianggap memiliki pengaruh positif yang signifikan pada timbulnya senjangan pada anggaran adalah partisipasi anggaran dan ambiguitas peran.

Partisipasi penganggaran merupakan hal yang sangat penting karena anggaran merupakan alat utama pemerintah untuk melaksanakan semua kewajiban, janji dan kebijakannya dalam rencana nyata dan terintegrasi dalam hal tindakan yang harus diambil, hasil yang akan dicapai, biaya yang dibutuhkan dan sumber-sumber biaya tersebut. Kebijakan anggaran mengekspresikan komitmen pemerintah kepada warganya secara konkrit (Laily, 2016). Menurut Tambunan, (2012) anggaran partisipatif sebenarnya dapat merusak motivasi bawahan dan menurunkan usaha untuk mencapai tujuan dari organisasi. Hal ini disebabkan oleh banyak faktor salah satunya siapa yang seharusnya dilibatkan dalam penyusunan anggaran dan keputusan apa saja yang memerlukan partisipasi. Keterlibatan individu dalam penyusunan anggaran terkadang menimbulkan masalah lain yaitu budgetary slack. Pello (2014), menyimpulkan bahwa tingkat partisipasi yang tinggi dapat menyebabkan tekanan sosial yang akhirnya memberi kesempatan dan motivasi untuk menciptakan senjangan anggaran. Hasil penelitian Dzaky et al., (2017), menunjukkan bahwa anggaran partisipatif berpengaruh signifikan terhadap perilaku disfungsional yaitu senjangan anggaran.

Penganggaran partisipatif berdampak langsung terhadap perilaku manusia (Ardan, 2014). Dampak tersebut dapat berupa perilaku positif maupun perilaku negatif. Perilaku positif akan timbul jika tujuan pribadi masing-masing manajer selaras, serasi, dan seimbang dengan tujuan perusahaan (goal congruence) dan manajer memiliki kemauan untuk memenuhinya (Safitri et al., 2015). Disisi lain, anggaran partisipatif juga dapat menimbulkan perilaku disfungsional (dysfunctional behaviour) yang pada dasarnya bertentangan dengan tujuan perusahaan. Salah satu wujud dari perilaku disfungsional tersebut adalah senjangan anggaran (budgetary slack). Senjangan anggaran didefinisikan sebagai selisih antara sumber daya yang sesungguhnya dibutuhkan untuk menyelesaikan pekerjaan secara efektif dengan sejumlah sumber daya yang ditambahkan untuk menyelesaikan pekerjaan tersebut (Alrasyid, 2017).

Penelitian tentang hubungan antara partisipasi anggaran dengan senjangan anggaran telah banyak dilakukan, namun dari hasil penelitian tersebut menunjukan terjadinya ketidakkonsistenan. Berdasarkan hasil penelitian Alrasyid (2017), Pello (2014), dan Irfan et al., (2016) menemukan bahwa partisipasi penganggaran berpengaruh positif signifikan terhadap senjangan anggaran. Hasil penelitian yang berbeda ditunjukan oleh beberapa peneliti diantaranya adalah Priliandani, (2016), Göhkan \& Emine, (2011) dan Zainuddin \& Isa, (2011) mengatakan bahwa partisipasi dalam penyusunan anggaran dapat mengurangi senjangan anggaran (budgetary slack).

Perbedaan hasil penelitian yang ada dapat diselesaikan melalui pendekatan kontigensi. Pemakaian pendekatan kontigensi memungkinkan untuk mengusulkan variabel lain yang diperkirakan juga berpengaruh pada hubungan 
antara partisipasi anggaran dan senjangan anggaran serta hubungan antara keterlibatan kerja dan senjangan anggaran. Dalam penelitian ini, peneliti menggunakan variabel karakter personal untuk menguji hubungan antara partisipasi anggaran dengan senjangan anggaran. Karakter personal dipilih karena seseorang memiliki sifat yang berbeda- beda.

Karakteristik individu mencakup sejumlah sifat dasar yang melekat pada individu tertentu. Menurut Winardi dalam Rahman (2013:77), karakteristik individu mencakup sifat-sifat berupa kemampuan dan keterampilan; latar belakang keluarga, sosial, dan pengalaman, umur, bangsa, jenis kelamin dan lainnya yang mencerminkan sifat demografis tertentu; serta karakteristik psikologis yang terdiri dari persepsi, sikap, kepribadian, belajar, dan motivasi. Lanjutnya, cakupan sifat-sifat tersebut membentuk suatu nuansa budaya tertentu yang menandai ciri dasar bagi suatu organisasi tertentu pula.

Dalam penelitian ini karakter personal dibagi menjadi dua sifat, yaitu rasa optimis dan pesimis (Zainuddin \& Isa, 2011). Jika seseorang memiliki rasa pesimisme sejak awal, maka berakibat pada kegagalan target yang ditetapkan sehingga akan menimbulkan kesenjangan. Sebaliknya, jika seseorang memiliki rasa optimisme, maka akan timbul sebuah ketahanan terhadap perubahan di masa mendatang, sehingga kesenjangan dapat dihindari. Penelitian sebelumnya yang menggunakan variabel ini adalah Pradnyandari \& Krisnadewi, (2014) menyatakan bahwa variabel karakteristik personal mampu memoderasi (memperlemah) hubungan antara partisipasi anggaran dengan senjangan anggaran.

Faktor kesenjangan anggaran selanjutnya adalah ambiguitas peran. Dzaky et al., (2017) menyatakan bahwa ambiguitas peran adalah ketidakbenaran informasi yang memadai diperlukan seseorang agar dapat menyelesaikan perannya secara optimal. Patria (2017) menyatakan bahwa jika seseorang mengalami ambiguitas peran, maka akan menyebabkan produktivitas rendah, ketegangan, dan ketidakpuasan. Seseorang yang mengalami ambiguitas peran tidak memeroleh kejelasan mengenai tugas-tugas dari pekerjaannya, antara lain disebabkan oleh job description yang tidak ditulis atau dijelaskan secara rinci, kurangnya pengetahuan orang tersebut dalam melaksanakan perannya, tidak adanya pengalaman dan ketidakpastian pengawasan oleh atasan. Orang yang mengalami ambiguitas peran tersebut harus menebak dan memprediksi sendiri setiap tindakannya. Hasil penelitian Febrisa (2012) menunjukan bahwa partisipasi penganggaran berpengaruh signifikan terhadap kesenjangan anggaran, ambiguitas peran memperkuat hubungan antara partisipasi penganggaran dengan kesenjangan anggaran.

Jika keterlibatan manajer level bawah dan menengah dalam menyusun anggaran dihubungkan dengan evaluasi kinerja, dan apabila kedua level di atas mengalami ambiguitas peran maka kedua level manajer di atas termotivasi untuk memberikan informasi yang bias agar kinerjanya terlihat baik (Ana \& Ratnadi, 2016). Anggaran yang disusun berdasarkan informasi bawahan yang bias, akan menyebabkan besaran anggaran tidak sesuai dengan estimasi sesungguhnya dan dapat dikatakan bahwa anggaran tersebut cenderung memiliki kesenjangan (slack). Alasan peneliti memilih lokasi penelitian pada perusahaan hotel berbintang di Kota Denpasar karena Denpasar pertumbuhan 
hotel berbintang yang relatif tinggi dan Kota Denpasar memiliki potensi pengembangan wisata kota atau kota wisata. Hotel berbintang dipilih sebagai objek penelitian karena hotel merupakan salah satu akomodasi pariwisata yang melaksanakan tujuan perusahaan berdasarkan anggaran (rencana kerja tahunan) yang dibuat sebagai acuan/patokan untuk mencapai tujuan dan digunakan untuk penilaian kinerja manajer. Penyusunan rencana kerja tahunan hotel biasanya melibatkan pengurus dan pejabat eksekutif atau manajer menengah yang ada pada struktur organisasi perhotelan. Maka dari itu penelitian ini mengidentifikasi secara menyeluruh bagaimana karakteristik personal sebagai pemoderasi pengaruh penganggaran partisipatif dan ambiguitas peran terhadap senjangan anggaran.

Ambiguitas peran sebagai variabel yang banyak dihubungkan dengan senjangan anggaran ditemukan memiliki pengaruh yang tidak konsisten Hasil penelitian Patria (2017) mengemukakan bahwa ambiguitas tidak berpengaruh terhadap terjadinya senjangan anggaran. Berbeda dengan hasil penelitian Ana \& Ratnadi, (2016) yang menemukan bahwa ambiguitas berpengaruh negatif terhadap senjangan anggaran. Govindarajan (1986) menyatakan bahwa perbedaan hasil penelitian tersebut dapat diselesaikan melalui pendekatan kontijensi (contingency approach). Hal ini dilakukan dengan memasukkan variabel lain yang mungkin mempengaruhi ambiguitas peran dengan senjangan anggaran.

Pengaruh ambiguitas peran dan senjangan anggaran di pengaruhi oleh beberapa variabel pemoderasi, dimana dalam penelitian ini akan digunakan variabel karakteristik personal. Karakteristik personal dipilih karena individu mempunyai sifat yang berbeda dalam tingkat kepercayaan diri dan pandangan pribadi atau terkait dengan kepribadian dari masing-masing terhadap keberhasilan yang akan dicapainya di masa depan (Putrid dan Wirama, 2016).

Penelitian terdahulu menemukan korelasi signifikan untuk faktor-faktor personal dengan melihat dampak karakteristik individual pada keterlibatan kerja, seperti tingginya kebutuhan terhadap kekuasaan serta keyakinan dalam etika kerja konvensional (Pratiwi, 2015). Karakteristk personal yang dimiliki setiap individu dibedakan menjadi dua, yaitu optimis dan pesimis (Simon et al., 2000). Apabila individu tidak memiliki karakteristik personal, maka individu tersebut cenderung memiliki sifat tidak percaya diri yang berakibat individu tersebut tidak memandang seberapa penting pekerjaan yang sedang dihadapinya yang mana nantinya akan berimbas pada saat melakukan perencanaan anggaran.

Partisipasi dalam proses penyusunan anggaran sebagai proses pengambilan keputusan bersama oleh dua bagian atau lebih pihak dimana keputusan tersebut akan memiliki masa depan terhadap mereka yang membuatnya (Arfan, 2011). Adanya partisipasi anggaran, bisa membuat bawahan memiliki kesempatan untuk memberitahukan informasi yang mereka ketahui kepada atasan, sehingga atasan nantinya dapat mebuat keputusan terbaik untuk organisasinya. Adanya partisipasi yang benar bukan partisipasi semu dalam proses penganggaran dapat mengurangi terjadinya slack (Irfan et al., 2016). Partisipasi rendah, maka kesempatan bagi manajer bawah untuk menciptakan senjangan dalam anggarannya sangat kecil dengan mengabaikan 
penyajian penekanan anggaran.

Hasil dari hipotesis adalah adanya pengaruh partisipasi anggaran terhadap senjangan anggaran (budgetary slack). Penelitian mengenai pengaruh karakteristik personal pada senjangan anggaran sejauh ini masih sedikit. Penelitian yang dilakukan oleh Maksum (2009) padaperusahaan manufaktur menunjukkan bahwa karakter personal mampu memoderasi hubungan antara partisipasi anggaran dengan senjangan anggaran. Penelitian yang dilakukan oleh Pradnyandari \& Krisnadewi, (2014) pada SKPD Provinsi Bali menunjukkan bahwa variabel karakteristik personal mampu memoderasi (memperlemah) hubungan antara partisipasi anggaran dengan senjangan anggaran. Hal ini berarti bahwa apabila penyusun anggaran memiliki karakteristik personal optimis, maka mereka akan memiliki rasa percaya diri dalam menyusun anggaran sehingga cenderung untuk tidak melakukan senjangan anggaran. Berdasarkan penelitian sebelumnya, dapat dirumuskan hipotesis sebagai berikut.

$\mathrm{H}_{1}$ : Karakteristik personal memperlemah pengaruh penganggaran partisipatif pada senjangan anggaran.

Seseorang yang mengalami ambiguitas peran tidak memeroleh kejelasan mengenai tugas-tugas dari pekerjaannya, antara lain disebabkan oleh job description yang tidak ditulis atau dijelaskan secara rinci, kurangnya pengetahuan orang tersebut dalam melaksanakan perannya, tidak adanya pengalaman dan ketidakpastian pengawasan oleh atasan. Orang yang mengalami ambiguitas peran tersebut harus menebak dan memprediksi sendiri setiap tindakannya.

Karakter personal dalam penelitian ini didefinisikan sebagai tingkat kepercayaan diri dan pandangan pribadi masing-masing responden terhadap keberhasilan yang akan dicapainya di masa depan. Karakteristk personal yang dimiliki setiap individu dibedakan menjadi dua, yaitu optimis dan pesimis (Simon et al., 2000). Hasil penelitian Pratiwi (2015) menjelaskan bahwa ambiguitas berpengaruh terhadap kesenjangan anggaran. Jadi berdasarkan pemaparan tersebut diatas dapat disimpulkan bahwa apabila individu tidak memiliki karakteristik personal, maka individu tersebut cenderung memiliki sifat tidak percaya diri yang berakibat individu tersebut tidak memandang seberapa penting pekerjaan yang sedang dihadapinya yang mana nantinya akan berimbas pada saat melakukan perencanaan anggaran. Berdasarkan pernyataan di atas, dapat dirumuskan hipotesis sebagai berikut.

$\mathrm{H}_{2}$ : Karakteristik personal memperlemah pengaruh keterlibatan kerja pada senjangan anggaran.

\section{METODE PENELITIAN}

Pendekatan yang digunakan dalam penelitian ini adalah pendekatan kuantitatif berbentuk asosiatif, yang bertujuan untuk mengetahui hubungan antara dua variabel atau lebih dan juga menguji hubungan variabel moderasi. Penelitian ini menggunakan data primer dengan menyebarkan kuesioner di hotel berbintang di Kota Denpasar.

Lokasi penelitian dalam penelitian ini adalah hotel berbintang di Kota Denpasar. Lokasi penelitian ini dipilih karena Kota Denpasar merupakan pusat ibu kota Provinsi Bali dan menjadi salah satu agenda destinasi dari kunjungan 
wisatawan baik lokal, domestik maupun mancaneegara. Hal ini akan menyebabkan agar setiap hotel dapat meningkatkan kinerjanya, sehingga dapat mendorong pengelola akan melakukan bugedatary slack untuk meningkatkan kualitas kerjanya.

Variabel terikat dalam penelitian ini adalah senjangan anggaran (Y). Senjangan anggaran yang dimaksud adalah tindakan seorang manajer yang mengecilkan kapabilitas produktifnya ketika manajer tersebut diberi kesempatan untuk menentukan standar kerjanya. Variabel senjangan anggaran diukur dengan menggunakan 5 indikator yang dikembangkan oleh Citra (2014), yaitu: produktivitas tinggi oleh penentuan standar dalam anggaran, pelaksanaan anggaran, adanya keterbatasan anggaran, target anggaran yang ketat dan tingkat efisiensi anggaran.

Variabel bebas dalam penelitian ini adalah partisipasi anggaran $\left(X_{1}\right)$ dan ambiguitas peran $\left(\mathrm{X}_{2}\right)$. Pengukuran pada partisipasi anggaran dikembangkan oleh Permata \& Wirasedana, (2015) yang terdiri dari 5 indikator, yaitu keterlibatan dalam penyusunan anggaran, frekuensi saran dalam anggaran, banyaknya pengaruh yang diberikan, pentingnya kontribusi dan frekuensi opini yang diberikan. Ambiguitas peran diukur menggunakan instrumen penelitian berupa kuesioner yang dikembangkan oleh Rizzo et al., (1970) yang terdiri dari 5 indikator yaitu sebagai berikut Pedoman (Guidelines), Tugas, Tanggung jawab, Standar pengendalian intern dan Pembagian waktu dalam mengevaluasi kelemahan pengendalian internal.

Variabel moderasi dalam penelitian ini adalah karakteristik personal (M). Karakteristik individu mencakup sejumlah sifat dasar yang melekat pada individu tertentu. Pengukuran variabel ini menggunakan 6 indikator yang dikembangkan oleh Ermawati \& Ardana, (2018) karakteristik individu meliputi sebagai berikut: minat, sikap tehadap diri sendiri, pekerjaan, dan situasi pekerjaan, kebutuhan individual, kemampuan dan kompetensi, pengetahuan tentang pekerjaan, emosi, suasana hati, perasaan keyakinan dan nilai-nilai.

Populasi dalam penelitian ini yaitu seluruh manajer baik manajer level menengah hingga manajer level atas pada Hotel bintang 4 di Kota Denpasar yang berjumlah 7 hotel (BPS Provinsi Bali, 2017), dimana dari masing-masing hotel akan di pilih 5 orang sebagai sampel yang terdiri dari manajer level menengah yang terdir atas manajer akunting, manajer pemasaran, manajer room divisi, manajer front office dan chief engeenering, jadi total populasi sebanyak 35 responden dengan metode pengumpulan data menggunakan kuisioner.

Teknik analisis yang digunakan dalam penelitian ini adalah Moderated Regression Analysis (MRA), yaitu untuk menguji hubungan antara penganggaran partisipatif dan ambiguitas peran pada senjangan anggaran dimana karakteristik personal digunakan sebagai variabel pemoderasi. Pengujian hipotesis dengan diformulasikan sebagai berikut.

$$
Y=a+b 1 X_{1}+b_{2} X_{2}+b_{3} X_{3}+b_{4}\left(X_{1} . X_{3}\right)+b 5\left(X_{2} . X_{3}\right)+\varepsilon
$$

Keterangan :

$$
\begin{array}{ll}
\mathrm{a} & =\text { Konstanta } \\
\mathrm{b} 1-\mathrm{b} 5 & =\text { Koefisien variabel-variabel independen } \\
\mathrm{Y} & =\text { Senjangan anggaran }
\end{array}
$$


$\mathrm{X}_{1} \quad=$ Penganggaran partisipatif

$\mathrm{X}_{2} \quad=$ Ambiguitas peran

$X_{3} \quad=$ Karakteristik personal

$\mathrm{X}_{1} \cdot \mathrm{X}_{3}=$ Interaksi antara penganggaran partisipatif dan senjangan anggaran

$\mathrm{X}_{2} \cdot \mathrm{X}_{3}=$ Interaksi antara ambiguitas peran dan senjangan anggaran

$\varepsilon=$ standar error (kekeliruan pengukuran dan pengaruh faktor lain)

\section{HASIL DAN PEMBAHASAN}

Pengujian validitas tiap butir digunakan analisis item yaitu mengkorelasikan skor tiap item dengan skor total item. Nilai korelasi antar skor item dengan total item kemudian dibandingkan dengan koefisien korelasi " $r$ ". Jika korelasi item terhadap skor total lebih besar dari koefisien korelasi " $r$ " $(0,30)$ maka instrumen dikatakan valid. Suatu kuesioner dikatakan valid jika pernyataan pada kuesioner mampu untuk mengungkapkan sesuatu yang diukur oleh kuesioner tersebut. Hasil uji validitas instrumen penelitian akan disajikan pada Tabel 1.

Tabel 1. Hasil Uji Validitas

\begin{tabular}{lccc}
\hline \multicolumn{1}{c}{ Variabel } & Pernyataan & Pearson Correlation & Keterangan \\
\hline Penganggaran & X1.1 & 0,751 & Valid \\
Partisipatif $\left(\mathrm{X}_{1}\right)$ & X1.2 & 0,691 & Valid \\
& X1.3 & 0,742 & Valid \\
& X1.4 & 0,691 & Valid \\
X1.5 & 0,371 & Valid \\
Ambiguitas & X2.1 & 0,944 & Valid \\
Peran $\left(\mathrm{X}_{2}\right)$ & X2.2 & 0,894 & Valid \\
& X2.3 & 0,981 & Valid \\
& X2.4 & 0,859 & Valid \\
X2.5 & 0,578 & Valid \\
Karakteristik & X3.1 & 0,698 & Valid \\
Personal $\left(\mathrm{X}_{3}\right)$ & X3.2 & 0,399 & Valid \\
& X3.3 & 0,399 & Valid \\
& X3.4 & 0,986 & Valid \\
& X3.5 & 0,834 & Valid \\
X3.6 & 0,834 & Valid \\
Senjangan & Y1 & 0,836 & Valid \\
Anggaran $(Y)$ & Y2 & 0,699 & Valid \\
& Y3 & 0,851 & Valid \\
& Y4 & 0,699 & Valid \\
& Y5 & 0,698 & Valid \\
\hline
\end{tabular}

Sumber: Data Penelitian, 2019

Tabel 1, menunjukkan bahwa seluruh indikator pernyataan dalam variabel penganggaran partisipatif, ambiguitas peran, karakteristik personal dan senjangan anggaran memiliki nilai pearson correlation yang lebih besar dari 0,30. Dengan demikian dapat disimpulkan bahwa seluruh indikator telah memenuhi syarat uji validitas.

Reliabilitas menunjukkan sejauh mana suatu alat pengukur dapat 
dipercaya atau dapat diandalkan. Apabila suatu alat pengukur dipakai dua kali untuk mengukur gejala yang sama dan hasil pengukuran yang diperoleh relatif konsisten, maka alat pengukur tersebut reliabel. Pengujian reliabilitas dalam penelitian ini menggunakan metode Cronbach's Alpha. Instrumen dikatakan reliabel untuk mengukur variabel bila berada di atas angka 0,60. Hasil pengujian reliabilitas instrumen dapat dilihat pada Tabel 2.

\section{Tabel 2. Hasil Uji Reliabilitas}

\begin{tabular}{lcc}
\multicolumn{1}{c}{ Variabel } & Cronbach's Alpha & Keterangan \\
\hline penganggaran partisipatif $\left(\mathrm{X}_{1}\right)$ & 0,807 & Reliabel \\
ambiguitas peran $\left(\mathrm{X}_{2}\right)$ & 0,819 & Reliabel \\
karakteristik personal $\left(\mathrm{X}_{3}\right)$ & 0,781 & Reliabel \\
senjangan anggaran $(\mathrm{Y})$ & 0,795 & Reliabel \\
\hline
\end{tabular}

Sumber: Data Penelitian, 2019

Berdasarkan Tabel 2, menjelaskan bahwa seluruh instrumen penelitian yang digunakan yaitu penganggaran partisipatif, ambiguitas peran, karakteristik personal dan senjangan anggaran memiliki koefisien Cronbach's Alpha lebih besar dari 0,60 sehingga instrumen yang digunakan dalam penelitian ini dinyatakan reliabel.

Uji asumsi klasik dilakukan dengan tujuan untuk memastikan hasil yang diperoleh memenuhi asumsi dasar di dalam analisis regresi. Hasil uji asumsi klasik yang dilakukan dalam penelitian ini adalah uji normalitas, uji multikoliniearitas, dan uji heteroskedastisitas. Uji ini bertujuan untuk mengetahui apakah residual dari model regresi yang dibuat berdistribusi normal atau tidak. Untuk menguji apakah data yang digunakan normal atau tidak dapat dilakukan dengan menggunakan uji Kolmogorov Sminarnov. Apabila koefisien Asymp. Sig. (2-tailed) lebih besar dari 0,05 maka data tersebut dikatakan berdistribusi normal. Hasil pengujian normalitas dapat dilihat pada Tabel 3, sebagai berikut.

Tabel 3. Hasil Uji Normalitas

\begin{tabular}{cr}
\hline & Unstandardized Residual \\
\hline $\mathrm{N}$ & 35 \\
Kolmogorov-Smirnov Z & 0,157 \\
Asymp.Sig.(2-tailed) & 0,200 \\
\hline
\end{tabular}

Sumber: Data Penelitian, 2019

Berdasarkan Tabel 3, dapat dilihat bahwa nilai Kolmogorov Sminarnov (K-S) sebesar 0,157, sedangkan nilai Asymp. Sig. (2-tailed) sebesar 0,200. Hasil tersebut mengindikasikan bahwa model persamaan regresi tersebut berdistribusi normal karena nilai Asymp. Sig. (2-tailed) 0,200 lebih besar dari nilai alpha 0,05.

Tabel 4. Hasil Uji Multikoleniaritas

\begin{tabular}{lll}
\hline \multicolumn{1}{c}{ Variabel } & Tolerance & VIF \\
\hline Penganggaran Partisipatif $\left(\mathrm{X}_{1}\right)$ & 0,382 & 2,616 \\
Ambiguitas Peran $\left(\mathrm{X}_{2}\right)$ & 0,348 & 2,872 \\
Karakteristik Personal $\left(\mathrm{X}_{3}\right)$ & 0,437 & 2,289 \\
$\mathrm{PP} \mathrm{KP}$ & 0,361 & 2,768 \\
$\mathrm{AP} \times \mathrm{KP}$ & 0,612 & 1,635 \\
\hline
\end{tabular}

Sumber: Data Penelitian, 2019

Berdasarkan Tabel 4, dapat dilihat bahwa nilai tolerance dan VIF dari 
masing-masing variabel menunjukkan bahwa nilai tolerance untuk setiap variabel lebih besar dari 10 persen dan nilai VIF lebih kecil dari 10 yang berarti model persamaan regresi bebas dari multikolinearitas.

Uji heteroskedastisitas dilakukan untuk mengetahui apakah dalam model regresi terjadi ketidaksamaan varian. Uji ini dapat dianalisis melalui uji gletser dengan melihat tingkat signifikansi, jika tingkat signifikansi berada di atas 0,05 maka model regresi ini bebas dari masalah heterokedastisitas.

Tabel 5. Hasil Uji Heteroskedastisitas

\begin{tabular}{lcc}
\hline \multicolumn{1}{c}{ Variabel } & Sig. & Keterangan \\
\hline Penganggaran Partisipatif $\left(\mathrm{X}_{1}\right)$ & 0,084 & Bebas heteroskedastisitas \\
Ambiguitas Peran $\left(\mathrm{X}_{2}\right)$ & 0,267 & Bebas heteroskedastisitas \\
Karakteristik Personal $\left(\mathrm{X}_{3}\right)$ & 0,545 & Bebas heteroskedastisitas \\
$\mathrm{PP}^{*} \mathrm{KP}$ & 0,088 & Bebas heteroskedastisitas \\
$\mathrm{AP} \mathrm{PP}^{*} \mathrm{O}$ & 0,326 & Bebas heteroskedastisitas \\
\hline
\end{tabular}

Sumber: Data Penelitian, 2019

Pada Tabel 5, dapat dilihat bahwa nilai sig. dari masing-masing variabel lebih besar dari 0,05 yang berarti tidak terdapat pengaruh antara variabel bebas terhadap absolute residual. Dengan demikian, model yang dibuat tidak mengandung gejala heteroskedastisitas.

Sebelum dilakukan pengujian hipotesis, satu hal yang perlu diperhatikan adalah kelayakan model penelitian yang dilakukan dengan uji $F$ untuk mengetahui pengaruh variabel-variabel independen pada variabel dependen. Sig. Tabel ANOVA menunjukkan besarnya angka probabilitas atau signifikansi pada perhitungan ANOVA. Nilai yang tertera digunakan untuk uji kelayanan Model Analisis (dimana sejumlah variabel x mempengaruhi variabel y) dengan ketentuan angka probabilitas yang baik untuk digunakan sebagai model regresi harus $<0,05$. Nilai ini bisa dilihat pada kolom Sig. Jika Sig. $<0,05$, maka Model Analisis dianggap layak. Jika Sig. $>0,05$, maka Model Analisis dianggap tidak layak.

Tabel 6. Hasil Uji Kelayakan Model (Uji F)

\begin{tabular}{ccccccc}
\hline Model & & $\begin{array}{c}\text { Sum of } \\
\text { Squares }\end{array}$ & Df & $\begin{array}{c}\text { Mean } \\
\text { Square }\end{array}$ & F & Sig. \\
\hline 1 & Regression & 60,450 & 5 & 12,090 & 9,815 & 0,000 \\
& & & & & \\
& Residual & 35,721 & 29 & 1,232 & & \\
\hline & Total & 96,171 & 34 & & & \\
\hline
\end{tabular}

Sumber: Data Penelitian, 2019

Hasil Uji Anova atau (F test) pada Tabel 6, menunjukan nilai F hitung sebesar 9,815 dengan signifikansi 0,000 yang probabilitas signifikan lebih kecil dari alpha 0,05. Ini menunjukan model yang digunakan pada penelitian ini adalah layak. Penganggaran partisipatif, ambiguitas peran, karakteristik personal, $\mathrm{PP} * \mathrm{KP}$ dan $\mathrm{AP}^{*} \mathrm{KP}$ dapat digunakan untuk memprediksi senjangan anggaran atau dapat dikatakan bahwa penganggaran partisipatif, ambiguitas peran, karakteristik personal, $\mathrm{PP} * \mathrm{KP}$ dan $\mathrm{AP}$ KP secara bersama-sama berpengaruh terhadap senjangan anggaran.

Adjusted $R$ Square sebesar 0,565 mempunyai arti bahwa sebesar 56,5 persen variasi senjangan anggaran dipengaruhi oleh variasi penganggaran partisipatif, 
ambiguitas peran, karakteristik personal, $\mathrm{PP} * \mathrm{KP}$ dan $\mathrm{AP} * \mathrm{KP}$, sedangkan sisanya sebesar 43,5 persen djelaskan oleh faktor lain yang tidak dimasukkan ke dalam model.

Moderated Regression Analysis (MRA) merupakan aplikasi khusus regresi berganda linear dimana dalam persamaan regresinya mengandung unsur interaksi (perkalian dua atau lebih variabel independen) yang dipengaruhi oleh variabel ketiga. MRA digunakan untuk menguji hubungan antara penganggaran partisipatif dan ambiguitas peran pada senjangan anggaran dimana karakteristik personal digunakan sebagai variabel pemoderasi. Hasil uji MRA dapat dilihat pada Tabel 7.

Tabel 7. Hasil Analisis Regresi Moderasi

\begin{tabular}{lrrrrrr}
\hline \multirow{2}{*}{ Model } & \multicolumn{2}{c}{$\begin{array}{l}\text { Unstandardized } \\
\text { Coefficients }\end{array}$} & \multicolumn{2}{c}{$\begin{array}{c}\text { Standardized } \\
\text { Coefficients }\end{array}$} & \multirow{2}{*}{ T } & Sig. \\
\cline { 2 - 4 } & \multicolumn{1}{c}{ Std. Error } & Beta & & \\
\hline (Constant) & 12,474 & 2,687 & & 4,643 & 0,000 \\
Penganggaran Partisipatif & 0,759 & 0,371 & 0,243 & 2,046 & 0,041 \\
Ambiguitas Peran & 1,868 & 0,704 & 0,509 & 2,654 & 0,013 \\
Karakteristik Personal & $-0,451$ & 0,182 & $-0,424$ & $-2,474$ & 0,019 \\
PP*KP & $-0,008$ & 0,003 & $-0,131$ & $-2,667$ & 0,016 \\
AP*KP & $-0,009$ & 0,004 & $-0,335$ & $-2,315$ & 0,028 \\
\hline
\end{tabular}

Sumber: Data Penelitian, 2019

Berdasarkan hasil analisis regresi linier berganda seperti yang disajikan pada Tabel 8 , maka persamaan regresinya adalah sebagai berikut: $\mathrm{Y}=12,474+0,759 \mathrm{X} 1+1,868 \mathrm{X} 2-0,451 \mathrm{X} 3-0,008 \mathrm{PP} * \mathrm{KP}-0,009 \mathrm{AP} * \mathrm{KP}+\varepsilon$

Berdasarkan dari hasil pengujian menunjukan bahwa karakteristik personal memperlemah pengaruh penganggaran partisipatif pada senjangan anggaran. Partisipasi dalam proses penyusunan anggaran sebagai proses pengambilan keputusan bersama oleh dua bagian atau lebih pihak dimana keputusan tersebut akan memiliki masa depan terhadap mereka yang membuatnya (Arfan, 2011). Adanya partisipasi anggaran, bisa membuat bawahan memiliki kesempatan untuk memberitahukan informasi yang mereka ketahui kepada atasan, sehingga atasan nantinya dapat mebuat keputusan terbaik untuk organisasinya. Adanya partisipasi yang benar bukan partisipasi semu dalam proses penganggaran dapat mengurangi terjadinya slack (Irfan dkk., 2014). Partisipasi rendah, maka kesempatan bagi manajer bawah untuk menciptakan senjangan dalam anggarannya sangat kecil dengan mengabaikan penyajian penekanan anggaran. Hasil dari hipotesis adalah adanya pengaruh partisipasi anggaran terhadap senjangan anggaran (budgetary slack).

Hasil penelitian ini sesuai dengan penelitian yang dilakukan oleh Maksum (2009) pada perusahaan manufaktur menunjukkan bahwa karakter personal mampu memoderasi hubungan antara partisipasi anggaran dengan senjangan anggaran. Penelitian ini juga disukung hasil penelitian Pradnyandari (2014) pada SKPD Provinsi Bali menunjukkan bahwa variabel karakteristik personal mampu memoderasi (memperlemah) hubungan antara partisipasi anggaran dengan senjangan anggaran. Hal ini berarti bahwa apabila penyusun anggaran memiliki karakteristik personal optimis, maka mereka akan memiliki rasa percaya diri dalam menyusun anggaran sehingga cenderung untuk tidak melakukan 
senjangan anggaran.

Berdasarkan dari hasil pengujian yang ditunjukan Tabel 6, menunjukan bahwa ambiguitas peran memperlemah pengaruh penganggaran partisipatif pada senjangan anggaran. Seseorang yang mengalami ambiguitas peran tidak memeroleh kejelasan mengenai tugas-tugas dari pekerjaannya, antara lain disebabkan oleh job description yang tidak ditulis atau dijelaskan secara rinci, kurangnya pengetahuan orang tersebut dalam melaksanakan perannya, tidak adanya pengalaman dan ketidakpastian pengawasan oleh atasan. Orang yang mengalami ambiguitas peran tersebut harus menebak dan memprediksi sendiri setiap tindakannya. Karakter personal dalam penelitian ini didefinisikan sebagai tingkat kepercayaan diri dan pandangan pribadi masing-masing responden terhadap keberhasilan yang akan dicapainya di masa depan. Karakteristk personal yang dimiliki setiap individu dibedakan menjadi dua, yaitu optimis dan pesimis (Simon et al., 2000). Hasil penelitian ini di dukung oleh hasil penelitian Pratiwi (2015) yang menjelaskan bahwa ambiguitas berpengaruh terhadap kesenjangan anggaran. Jadi berdasarkan pemaparan tersebut diatas dapat disimpulkan bahwa apabila individu tidak memiliki karakteristik personal, maka individu tersebut cenderung memiliki sifat tidak percaya diri yang berakibat individu tersebut tidak memandang seberapa penting pekerjaan yang sedang dihadapinya yang mana nantinya akan berimbas pada saat melakukan perencanaan anggaran.

\section{SIMPULAN}

Berdasarkan hasil analisis maka dapat ditarik kesimpulan yaitu karakteristik personal memperlemah pengaruh penganggaran partisipatif pada senjangan anggaran. Hal ini menunjukkan bahwa apabila penyusun anggaran memiliki karakteristik personal optimis, maka mereka akan memiliki rasa percaya diri dalam menyusun anggaran sehingga cenderung untuk tidak melakukan senjangan anggaran. Karakteristik personal memperlemah pengaruh ambiguitas peran pada senjangan anggaran. Hal ini menunjukkan bahwa apabila individu tidak memiliki karakteristik personal, maka individu tersebut cenderung memiliki sifat tidak percaya diri yang berakibat individu tersebut tidak memandang seberapa penting pekerjaan yang sedang dihadapinya yang mana nantinya akan berimbas pada saat melakukan perencanaan anggaran.

Saran yang dapat diberikan dari hasil penelitian adalah Penganggaran partisipatif, ambiguitas peran, dan karakteristik personal. Berdasarkan hal tersebut maka manajemen perlu meningkatkan penganggaran partisipatif. Cara yang dapat dilakukan adalah dengan memberikan ruang untuk menyatakan pendapat dan usulan tentang anggaran kepada pimpinan tanpa diminta sehingga senjangan anggaran dapat dikurangi. Manajemen juga perlu menghindari terjadinya ambiguitas peran. Cara yang dapat dilakukan adalah dengan percaya terhadap wewenang yang saya miliki (misalnya untuk memutuskan hal-hal yang berkaitan dalam penugasan). Selain itu dari pimpinan harus mempu meningkatkan keyakinan atas kemampuan bawahannya dalam mengatasi tantangan. 


\section{REFERENSI}

Ajibolade, Solabomi O., Opeyemi Kehinde A. 2013. The Influence Of Organisational Culture And Budgetary Participation On Propensity To Create Budgetary Slack In Public Sector Organisations. British Journal Of Arts And Social Sciences, 13 (1), Pp: 69-83.

Ana, M. Y., \& Ratnadi, N. M. D. (2016). Pengaruh Partisipasi Penganggaran Pada Kesenjangan Anggaran Dengan Ambiguitas Peran Sebagai Variabel Pemoderasi. E-Jurnal Akuntansi; Vol 16 No 1 (2016). Https:/ /Ojs.Unud.Ac.Id/Index.Php/Akuntansi/Article/View/21671

Ardan Ari, I, And Putra. 2014. "Pengaruh Partisipasi Penganggaran, Asimetri Informasi, Self Esteem Dan Budget Emphasis Pada Budgetary Slack." EJournal Universitas Udayana 7 (3): 700-713.

Dzaky, M., Rasuli, M., \& Silfi, A. (2017). Pengaruh Partisipasi Anggaran Terhadap Senjangan Anggaran Pemerintah Daerah Dengan Gaya Kepemimpinan, Karakter Personal, Kapasitas Individu, Dan Komitmen Organisasi Sebagai Variabel Moderating (Survei Pada Skpd Kabupaten Kampar). Jurnal Online Mahasiswa Fakultas Ekonomi Universitas Riau, 4(1), 1684-1698.

Http://Jom.Unri.Ac.Id/Index.Php/Jomfekon/Article/View/13008

Ermawati, N. P. D., \& Ardana, I. K. (2018). Pengaruh Kepemimpinan Transformasional, Budaya Organisasi, Dan Motivasi Terhadap Komitmen Organisasional Pada Bpr Di Kabupaten Klungkung. E-Jurnal Manajemen Universitas Udayana. Https:/ / Doi.Org/10.24843/Ejmunud.2018.V07.I11.P19

Göhkan, Ö., \& Emine, Y. (2011). Effects Of Procedural Justice Perception , Budgetary Control Effectiveness And Ethical Work Climate On Propensity To Create Budgetary Slack. Business And Economics Research Journal, 2(4), 118. Https://Ssrn.Com/Abstract $=1946233$

Irfan, M., Santoso, B., \& Effendi, L. (2016). Pengaruh Partisipasi Anggaran Terhadap Senjangan Anggaran Dengan Asimetri Informasi, Penekanan Anggaran Dan Komitmen Organisasional Sebagai Variabel Pemoderasi. Jurnal Akuntansi Dan Investasi, 17(2), 158-175. Https:/ / Doi.Org/10.18196/Jai.2016.0052.158-175.

Laily, Maghfiroh Nur. 2016. Pengaruh Partisipasi Penyusunan Anggaran Terhadap Kualitas Anggaran. Jurnal Ilmiah Mahasiswa. H: 1-6.

Maksum, Azhar. 2009. Peran Ketidakpastian Lingkungan Dan Karakter Personal Dalam Memoderasi Pengaruh Partisipasi Anggaran Terhadap Senjangan Anggaran. Jurnal Keuangan Dan Bisnis Vol. 1, No.1.

Paul, J., Hermel, P., \& Srivatava, A. (2017). Entrepreneurial Intentions - Theory And Evidence From Asia, America, And Europe. Journal Of International Entrepreneurship, 15(3), 324-351. Https://Doi.Org/10.1007/S10843-0170208-1

Pello, Elisabeth V. 2014. "Pengaruh Asimetri Informasi Dan Locus Of Control Terhadap Hubungan Antara Penggaran Partisipatif Dan Senjangan Anggaran." E-Journal Universitas Udayana 6 (2): 287-305

Permata, R. A. C. M. R., \& Wirasedana, I. W. P. (2015). Pengaruh Partisipasi Penganggaran Pada Senjangan Anggaran Dengan Group Cohesiveness Sebagai Variabel Pemoderasi. E-Jurnal Akuntansi, 13(2), 418-428. 
Https://Ojs.Unud.Ac.Id/Index.Php/Akuntansi/Article/View/10069

Pradnyandari, A. A. S. S. D., \& Krisnadewi, K. A. (2014). Pengaruh Partisipasi Anggaran Pada Senjangan Anggaran Dengan Gaya Kepemimpinan Dan

Karakter Personal Sebagai Pemoderasi. E-Jurnal Akuntansi Universitas Udayana, $9(1)$, $17-26$.

Https://Ojs.Unud.Ac.Id/Index.Php/Akuntansi/Article/View/8610

Rizzo, J. R., House, R. J., \& Lirtzman, S. I. (1970). Role Conflict And Ambiguity In Complex Organizations. Administrative Science Quarterly, 15(2), 150-163. Https:/ / Doi.Org/10.2307/2391486

Safitri, D., Rasuli, M., \& Yeandrawita, Y. (2015). Pengaruh Partisipasi Anggaran, Informasi Asimetri, Kompleksitas Tugas Dan Penekanan Anggaran Terhadap Senjangan Anggaran Pada Instansi Pemerintah Daerah (Survei Pada Skpd Pemerintah Kabupaten Bengkalis). Jurnal Online Mahasiswa Fakultas Ekonomi Universitas Riau, 2(2), 33977. Https://Jom.Unri.Ac.Id/Index.Php/Jomfekon/Article/View/9024

Simon, M., Houghton, S., \& Aquino, K. (2000). Cognitive Biases, Risk Perception, And Venture Formation: How Individuals Decide To Start Companies. Journal Of Business Venturing, 15, 113-134.

Tambunan, I. D. (2012). Pengaruh Penganggaran Partisipatif Terhadap Kelonggaran Anggarandengan Asimetri Informasi Dan Locus Of Control Sebagai Variabel Moderating. Jom. Fekon, 2(1), 1-15. Https://Jom.Unri.Ac.Id/Index.Php/Jomfekon/Article/View/8200/7871

Zainuddin, S., \& Isa, C. R. (2011). The Role Of Organizational Fairness And Motivation In The Relationship Between Budget Participation And Managerial Performance: A Conceptual Paper. Australian Journal Of Basic And Applied Sciences, 5(12), 641-648. 